\title{
Mechanistic and Structural Determinants of NMDA Receptor Voltage-Dependent Gating and Slow $\mathrm{Mg}^{2+}$ Unblock
}

\author{
Richard J. Clarke, Nathan G. Glasgow, and Jon W. Johnson \\ Department of Neuroscience and Center for Neuroscience, University of Pittsburgh, Pittsburgh, Pennsylvania 15260
}

\begin{abstract}
NMDA receptor (NMDAR)-mediated currents depend on membrane depolarization to relieve powerful voltage-dependent NMDAR channel block by external magnesium $\left(\mathrm{Mg}_{\mathrm{o}}^{2+}\right) \cdot \mathrm{Mg}_{\mathrm{o}}^{2+}$ unblock from native NMDARs exhibits a fast component that is consistent with rapid $\mathrm{Mg}_{\mathrm{o}}^{2+}$-unbinding kinetics and also a slower, millisecond time scale component (slow $\mathrm{Mg}_{\mathrm{o}}^{2+}$ unblock). In recombinant NMDARs, slow $\mathrm{Mg}_{\mathrm{o}}^{2+}$ unblock is prominent in GluN1/2A (an NMDAR subtype composed of GluN1 and GluN2A subunits) and GluN1/2B receptors, with slower kinetics observed for GluN1/2B receptors, but absent from GluN1/2C and GluN1/2D receptors. Slow $\mathrm{Mg}^{2+}$ unblock from GluN1/2B receptors results from inherent voltage-dependent gating, which increases channel open probability with depolarization. Here we examine the mechanisms responsible for NMDAR subtype dependence of slow $\mathrm{Mg}_{\mathrm{o}}^{2+}$ unblock. We demonstrate that slow $\mathrm{Mg}_{\mathrm{o}}^{2+}$ unblock from GluN1/2A receptors, like GluN1/2B receptors, results from inherent voltage-dependent gating. Surprisingly, GluN1/2A and GluN1/2B receptors exhibited equal inherent voltage dependence; faster $\mathrm{Mg}_{\mathrm{o}}^{2+}$ unblock from GluN1/2A receptors can be explained by voltage-independent differences in gating kinetics. To investigate the absence of slow $\mathrm{Mg}_{\mathrm{o}}^{2+}$ unblock in GluN1/2C and GluN1/2D receptors, we examined the GluN2 S/L site, a site responsible for several NMDAR subtype-dependent channel properties. Mutating the GluN2 S/L site of GluN2A subunits from serine (found in GluN2A and GluN2B subunits) to leucine (found in GluN2C and GluN2D) greatly diminished both voltage-dependent gating and slow $\mathrm{Mg}_{\mathrm{o}}^{2+}$ unblock. Therefore, the residue at the GluN2 S/L site governs the expression of both slow $\mathrm{Mg}_{\mathrm{o}}^{2+}$ unblock and inherent voltage dependence.
\end{abstract}

\section{Introduction}

NMDA receptors (NMDARs) are ionotropic glutamate receptors critically involved in nervous system physiology and pathology and are tetramers usually composed of GluN1 and GluN2 subunits. NMDARs can be divided into four principal subtypes defined by the GluN2 subunit included in the receptor: GluN1/2A (composed of GluN1 and GluN2A subunits), GluN1/2B, GluN1/ $2 \mathrm{C}$, and GluN1/2D receptors. NMDARs display diverse pharmacological and biophysical properties that vary among NMDAR subtypes (Monyer et al., 1992; Stern et al., 1992; Kuner and Schoepfer, 1996; Cull-Candy and Leszkiewicz, 2004; Erreger et al., 2005; Traynelis et al., 2010). The NMDAR subtype dependence of gating-related properties, including agonist affinity and channel open probability, is controlled by divergence among GluN2 subunits of the extracellular N-terminal domain (Gielen et al., 2009; Yuan et al., 2009). The NMDAR subtype dependence of channel-related properties, including inhibition by extracellular magnesium $\left(\mathrm{Mg}_{\mathrm{o}}^{2+}\right), \mathrm{Ca}^{2+}$ permeability, and single-channel

Received Aug. 2, 2012; revised Jan. 4, 2013; accepted Jan. 11, 2013.

Author contributions: R.J.C., N.G.G., and J.W.J. designed research; R.J.C. and N.G.G. performed research; and R.J.C., N.G.G., and J.W.J. analyzed data and wrote the paper.

Support for this work was from National Institutes of Health Grants R01 MH045817 (to J.W.J.), T32 MH18273 to (R.J.C.), and T32 NS007433 and T32 NS073548 (to N.G.G.). We thank Karen Bouch and Christen Shiber for excellent technical assistance.

The authors declare no competing financial interests.

Correspondence should be addressed to Jon W. Johnson, Department of Neuroscience, A210 Langley Hall, University of Pittsburgh, Pittsburgh, PA 15260. E-mail: jjohnson@pitt.edu.

DOI:10.1523/JNEUROSCI.3712-12.2013

Copyright $\odot 2013$ the authors $\quad 0270-6474 / 13 / 334140-11 \$ 15.00 / 0$ conductance, is controlled by divergence among GluN2 subunits of the amino acid residue at a single site (Siegler Retchless et al., 2012). The site, termed the GluN2 S/L site, is located in the M3 transmembrane region.

Near typical resting potentials, endogenous $\mathrm{Mg}_{\mathrm{o}}^{2+}$ powerfully blocks the channels of NMDARs. GluN1/2A and GluN1/2B receptors are approximately fivefold more potently inhibited by $\mathrm{Mg}_{\mathrm{o}}^{2+}$ than GluN1/2C and GluN1/2D receptors (Monyer et al., 1992; Kuner and Schoepfer, 1996; Qian et al., 2005). Upon depolarization, $\mathrm{Mg}_{\mathrm{o}}^{2+}$ block of all NMDAR subtypes is relieved. The speed of depolarization-induced $\mathrm{Mg}_{\mathrm{o}}^{2+}$ unblock also varies strongly among NMDAR subtypes: $\mathrm{Mg}_{\mathrm{o}}^{2+}$ unblock from GluN1/2C and GluN1/2D receptors is very rapid, whereas $\mathrm{Mg}_{\mathrm{o}}^{2+}$ unblock from GluN1/2A and GluN1/2B receptors displays both a rapid component and a slow component that is slower for GluN1/2B receptors (Clarke and Johnson, 2006).

The slow component of $\mathrm{Mg}_{\mathrm{o}}^{2+}$ unblock from GluN1/2A and GluN1/2B receptors was unexpected based on the rapid kinetics of $\mathrm{Mg}_{\mathrm{o}}^{2+}$ unbinding from open channels (Nowak et al., 1984; Ascher and Nowak, 1988). Slow $\mathrm{Mg}_{\mathrm{o}}^{2+}$ unblock can be reproduced by models in which the rates of gating, desensitization, and/or agonist binding are altered when the channel is blocked by $\mathrm{Mg}_{\mathrm{o}}^{2+}$ (Kampa et al., 2004; Vargas-Caballero and Robinson, 2004). In contrast, we demonstrated previously that GluN1/2B receptors exhibit inherent (in the absence of $\mathrm{Mg}_{\mathrm{o}}^{2+}$ ) voltagedependent gating and that slow $\mathrm{Mg}_{\mathrm{o}}^{2+}$ unblock from GluN1/2B receptors results from voltage-dependent gating (Clarke and Johnson, 2008). These data reconciled for GluN1/2B receptors the characteristics of slow $\mathrm{Mg}_{\mathrm{o}}^{2+}$ unblock with evidence that 
$\mathrm{Mg}_{\mathrm{o}}^{2+}$ block does not affect transitions among receptor states (Sobolevsky and Yelshansky, 2000; Qian et al., 2002; Blanpied et al., 2005).

Here we demonstrate that GluN1/2A receptors exhibit inherent voltage-dependent gating. We show that voltage-dependent gating leads to slow $\mathrm{Mg}_{\mathrm{o}}^{2+}$ unblock with glutamate concentrationdependent kinetics and to voltage dependence of synaptic response decay kinetics. We also determined the origins of NMDAR subtype dependence of voltage-dependent gating and slow $\mathrm{Mg}_{\mathrm{o}}^{2+}$ unblock. Our finding that mutating the GluN2 S/L site, which was shown to modify multiple other NMDAR channel properties, also attenuated slow $\mathrm{Mg}_{\mathrm{o}}^{2+}$ unblock and voltagedependent gating, provides insight into mechanisms that may underlie both phenomena.

\section{Materials and Methods}

Cell culture and transfection. Experiments were performed on human embryonic kidney (HEK) 293T cells, which were maintained as described previously (Qian et al., 2005), or on tsA cells, which were similarly maintained except that $10 \%$ (rather than $5 \%$ ) fetal bovine serum was added to the culture medium. Cells were plated onto glass coverslips, either untreated or pretreated with poly D-lysine $(0.1 \mathrm{mg} / \mathrm{ml})$ and rat-tail collagen $(0.1 \mathrm{mg} / \mathrm{ml}, \mathrm{BD}$ Biosciences $)$, in $35 \mathrm{~mm}$ culture dishes at $1-2 \times 10^{5}$ cells per dish. Eighteen to $24 \mathrm{~h}$ after plating the cells were transiently transfected with cDNAs encoding the GluN1-1a (GenBank X63255 in pcDM8) and GluN2A (GenBank M91561 in pcDNA1) or GluN2A(S632L) (in pcDNA1) (Siegler Retchless et al., 2012) subunit using a $\mathrm{Ca}^{2+}$ precipitation method (Qian et al., 2005) or FuGENE transfection reagents (Promega). cDNA for enhanced green fluorescent protein (eGFP) was cotransfected to identify transfected cells. The following amounts of cDNAs were added to each dish: $0.5-0.7 \mu \mathrm{g}$ of eGFP, $0.5-1.3$ $\mu \mathrm{g}$ of GluN1-1a, and 1-2 $\mu \mathrm{g}$ of GluN2A or GluN2A(S632L). Cells were incubated with the transfection solution for $6-8 \mathrm{~h}$ and then precipitates were washed off with culture medium containing 200-1000 $\mu \mathrm{M}$ APV and either $2 \mathrm{mM} \mathrm{Mg}^{2+}$ or $200 \mu \mathrm{M} 7$-chlorokynurentic acid. Experiments were performed 20-72 h after transfection.

Solutions. Solutions were prepared from frozen stocks before experiments. Currents were activated by the indicated concentration of NMDA or glutamate. Glycine $(10 \mu \mathrm{M})$ was added to all solutions. The external

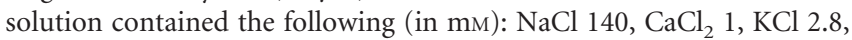
HEPES 10 , and either 0,1 , or $5 \mathrm{Mg}^{2+}, \mathrm{pH} 7.2$ adjusted with $\mathrm{NaOH}$, osmolality $290 \pm 10 \mathrm{mmol} / \mathrm{kg}$. Other external solutions used are described in Results. The pipette solution contained the following (in $\mathrm{mm}$ ): $\mathrm{CsCl}$ 125, EGTA 10, and HEPES 10, pH 7.2 adjusted with CsOH, osmolality $275 \pm 10 \mathrm{mmol} / \mathrm{kg}$. Sucrose was added if needed to adjust the osmolality of the external solution. All membrane voltages were corrected for the junction potential between the pipette and bath solution of $5 \mathrm{mV}$. Ultrapure salts were used if available. All chemicals were from Sigma.

Whole-cell recording. Whole-cell recordings from transfected HEK 293T or tsA cells were performed as described previously (Qian et al., 2005). All experiments were performed at room temperature. Pipettes were pulled from borosilicate standard-walled glass with filaments (1.5 $\mathrm{mm}$ outer diameter; $0.86 \mathrm{~mm}$ inner diameter; Warner Instruments) and fire polished (resistance, $2-5 \mathrm{M} \Omega$ ). Membrane current was recorded with an Axopatch 200 or 200B amplifier (Molecular Devices) in voltage-clamp mode. Series resistance correction and prediction circuitry were set to at least $80 \%$ in all experiments. Signals were low-pass filtered at a cutoff frequency of 2.5 or $5 \mathrm{kHz}$ (8-pole Bessel; Warner Instruments), sampled at $10-50 \mathrm{kHz}$, and refiltered at $1 \mathrm{kHz}$ for analysis and display.

Solutions were delivered using a fast perfusion system (Qian et al., 2002) connected to gravity-fed reservoirs (AutoMate Scientific). Solution exchange speed was estimated by recording whole-cell current from a transfected cell while moving between a solution with normal external solution plus $30 \mu \mathrm{M}$ NMDA and $10 \mu \mathrm{M}$ glycine and another solution that was identical except that the impermeant ion $\mathrm{NMDG}^{+}$replaced $\mathrm{Na}^{+}$. The time course of current decrease upon movement into the $\mathrm{NMDG}^{+}$ extracellular solution was used to estimate the time course of solution exchanges, which were $>90 \%$ complete within $20 \mathrm{~ms}$.

Data analysis and kinetic modeling. GluN1/2A receptor current responses were corrected for leak and capacitive currents by subtracting currents measured in 0 glutamate from currents measured in the presence of glutamate using identical voltage protocols. Examples of presubtraction and postsubtraction currents using identical procedures (except with GluN1/2B receptors) can be found in Figure 1 in Clarke and Johnson (2008). All current traces presented here are leak and capacitance subtracted. Current relaxations were fit with multiexponential equations as described previously (Clarke and Johnson, 2008). The number of exponential components was adjusted as necessary to provide high-quality fits as determined visually. Curve fitting was performed using Clampfit 9.2 or 10.3 (Molecular Devices) or Origin 7.0 (OriginLab) software.

Double-exponential fits to leak- and capacitance-subtracted wholecell currents (Fig. 1C) were used to generate the data plotted in Figures $1 D-F$ and $3, B$ and $C$. The fast component of the fits (time constant $=$ $\left.\tau_{\text {fast }}\right)$ resulted from voltage step-induced changes in driving force on current through open NMDARs. The value of $\tau_{\text {fast }}$ reflects technical limitations in patch-clamp experiments (Levis and Rae, 1992), including the speed of the voltage change during the step, and therefore does not provide physiologically relevant information. The mechanisms responsible for the slow component (amplitude as a percentage of entire current relaxation $=A_{\text {slow }}$; time constant $=\tau_{\text {slow }}$ ) were investigated here.

We performed three tests to determine whether measurement procedures affected $A_{\text {slow }}$ or $\tau_{\text {slow }}$ values. First, to determine whether, despite series resistance compensation, series resistance errors affected $A_{\text {slow }}$ values, we investigated whether $A_{\text {slow }}$ depended on the amplitude of the change in current (Total $\Delta \mathrm{I}$ ) during the largest depolarization used $(-100$ to $190 \mathrm{mV})$. A least-squares linear regression performed on a plot of $A_{\text {slow }}$ (range, $45.0-55.4 \%$ ) as a function of Total $\Delta \mathrm{I}$ (range, 1.5-7.8 nA) for each of the 6 cells in which measurements were made revealed no correlation $(p=0.28)$. Therefore, it is unlikely that series resistance error affected our measurements of $A_{\text {slow. }}$. Second, to determine whether lowpass filtering at $1 \mathrm{kHz}$ affected $A_{\text {slow }}$ or $\tau_{\text {slow }}$, we compared $A_{\text {slow }}$ and $\tau_{\text {slow }}$ values for three voltage steps (from $-100 \mathrm{mV}$ to 40,100 , and $190 \mathrm{mV}$ ) after low-pass filtering at $1 \mathrm{kHz}$ to values after filtering at $2.5 \mathrm{kHz}$. Filter frequency did not significantly ( $p>0.15$ for each comparison) affect $A_{\text {slow }}$ or $\tau_{\text {slow }}$ for any of the three voltage steps. Therefore, $1 \mathrm{kHz}$ low-pass filtering does not appear to have affected quantification of $A_{\text {slow }}$ or $\tau_{\text {slow }}$. We also compared values of $\tau_{\text {fast }}$ after low-pass filtering at $1 \mathrm{kHz}$ and at $2.5 \mathrm{kHz}$ and found no significant differences for voltage steps to 40 or 100 $\mathrm{mV}$, but $\tau_{\text {fast }}$ was significantly ( $p<0.003$; decrease of nearly twofold) faster after $2.5 \mathrm{kHz}$ filtering for voltage steps to $190 \mathrm{mV}$. Therefore, $1 \mathrm{kHz}$ low-pass filtering did in some cases affect $\tau_{\text {fast }}$ values (range, $0.089-0.593$ $\mathrm{ms}$ ), as expected for this fast component of current relaxations. Third, to determine whether use of double-exponential fits affected $A_{\text {slow }}$ or $\tau_{\text {slow }}$ we performed single-exponential fits to only the slow component of current relaxations for the same three voltage steps (from $-100 \mathrm{mV}$ to 40,100 , and $190 \mathrm{mV}$ ). To avoid interference from the fast component, fits were started $0.3 \mathrm{~ms}$ (twice the average $\tau_{\text {fast }}$ of $\sim 0.15 \mathrm{~ms}$, a delay that excluded most of the fast component without missing a significant portion of the slow component) after completion of the voltage step. The values of $A_{\text {slow }}$ and $\tau_{\text {slow }}$ based on single-exponential fits (to $2.5 \mathrm{kHz}$ filtered currents) and based on double-exponential fits (to $1 \mathrm{kHz}$ filtered currents) did not differ significantly for any of the three voltage steps ( $p>0.12$ for each comparison). Therefore, our standard measurement procedures (double-exponential fits to $1 \mathrm{kHz}$ filtered currents) appear to have provided reliable measurements of $A_{\text {slow }}$ and $\tau_{\text {slow. }}$.

To generate Figure 3, $B$ and $C$, for voltage steps from $-100 \mathrm{mV}$ to each plotted ending voltage $\left(V_{\mathrm{m}, \mathrm{e}}\right)$, the amplitudes for each $V_{\mathrm{m}, \mathrm{e}}$ of the fast $\left[I_{\text {fast }}\left(V_{\mathrm{m}, \mathrm{e}}\right)\right]$ and slow $\left[I_{\text {slow }}\left(V_{\mathrm{m}, \mathrm{e}}\right)\right]$ current components were first measured using double-exponential fits. $I_{\text {fast }}\left(V_{\mathrm{m}, \mathrm{e}}\right)$ and $I_{\text {slow }}\left(V_{\mathrm{m}, \mathrm{e}}\right)$ were then converted to fast and slow conductances (Clarke and Johnson, 2008). To permit averaging of conductance values across cells, each conductance value was normalized to the fast conductance measured during the largest depolarization ( -100 to $190 \mathrm{mV}$ ), which was performed in each cell. Because $I_{\text {fast }}$ results from the change in driving force on current flow through NMDARs open at $-100 \mathrm{mV}, g_{\text {fast }}$ was calculated as $I_{\text {fast }}\left(V_{\mathrm{m}, \mathrm{e}}\right) /$ 

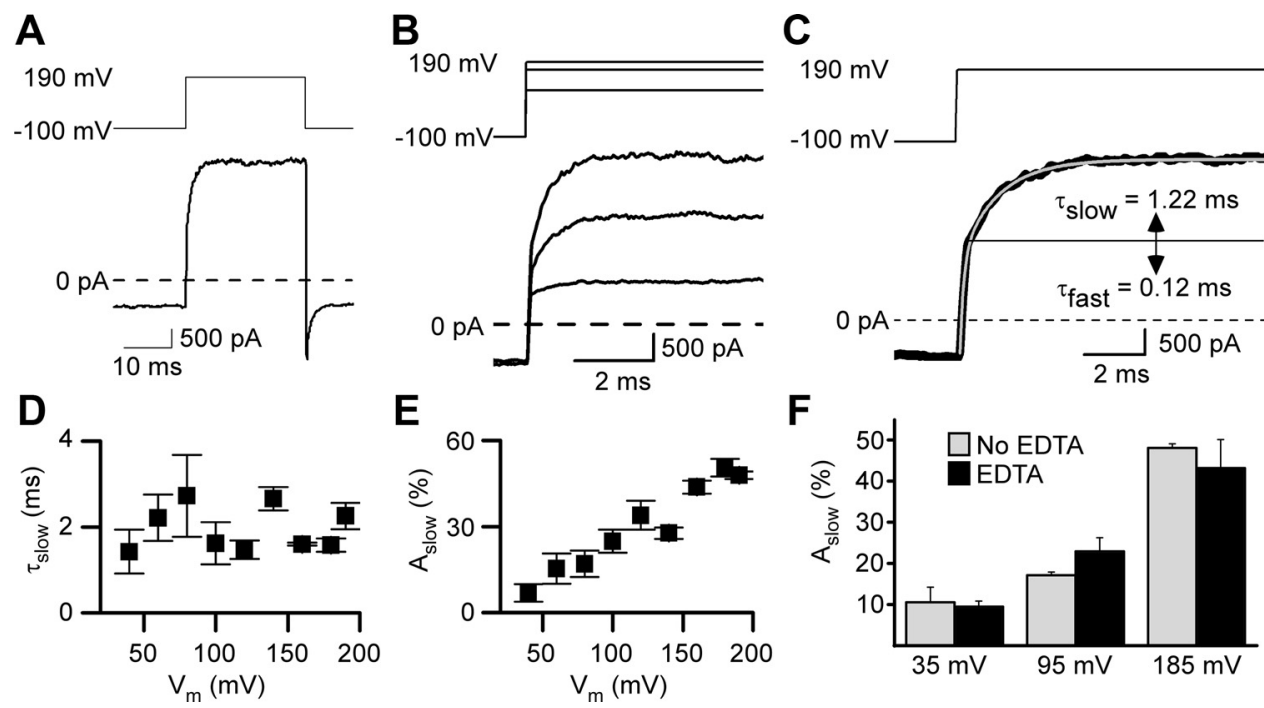

Figure 1. GluN1/2A receptor current relaxations after depolarizing steps display a slow component in $0 \mathrm{Mg}_{0}^{2+}$. $\boldsymbol{A}$, Whole-cell current recording from an HEK $293 \mathrm{~T}$ cell-expressing GluN1/2A receptors during application of $1 \mathrm{~mm}$ glutamate and $10 \mu \mathrm{m}$ glycine in $0 \mathrm{Mg}_{0}^{2+}$. After the inward current response (bottom trace) reached a steady-state level, a depolarizing step from -100 to 190 $\mathrm{mV}$ (top trace) was applied. Leak and capacitive currents were subtracted in all figures. $\boldsymbol{B}$, Voltage steps (top traces) and current responses (bottom traces) from the cell used for $\boldsymbol{A}$ with expanded time base during depolarizations from - 100 to 80, 160, and $190 \mathrm{mV}$. C, Voltage step (top trace) and current response (bottom trace, thick line) replotted from $\boldsymbol{A}$ with a double-exponential fit (bottom trace, thin gray line) superimposed. Time constants of fast and slow components of the current relaxation are given; slow component of the current trace appears above the solid horizontal line. $D$, $\tau_{\text {slow }}$ did not depend significantly on the voltage during the depolarizing step (based on least-squares linear regression, $p=0.80$ ) nor did $\tau_{\text {fast }}$ ( $p=0.46$; data not shown). $\boldsymbol{E}, A_{\text {slow }}$ as a percentage of the amplitude of the entire current relaxation induced by the depolarizing step increased with depolarization. $\boldsymbol{F}$, Addition of $10 \mu \mathrm{m}$ EDTA to normal external solution (No EDTA) did not affect $A_{\text {slow }}$ significantly ( $p>0.25$ at each voltage; $n=3$ for each condition) after depolarizing steps from $-105 \mathrm{mV}$ to 35,95 , or $185 \mathrm{mV}$.

Table 1. Rates used for GluN1/2A receptor model fitting and current simulations

\begin{tabular}{llc}
\hline Rate constant & Units & Value \\
\hline$k_{\text {on }}$ & $\mu \mathrm{M}^{-1} \mathrm{~s}^{-1}$ & 31.6 \\
$k_{\mathrm{off}}$ & $\mathrm{s}^{-1}$ & 1010 \\
$k_{\mathrm{s}+}$ & $\mathrm{s}^{-1}$ & $230^{a}$ \\
$k_{\mathrm{s}-}$ & $\mathrm{s}^{-1}$ & 178 \\
$k_{\mathrm{f}+}$ & $\mathrm{s}^{-1}$ & 3140 \\
$k_{\mathrm{f}--}$ & $\mathrm{s}^{-1}$ & 174 \\
$k_{\mathrm{d} 1+}$ & $\mathrm{s}^{-1}$ & Determined by fitting \\
$k_{\mathrm{d} 1+}$ & $\mathrm{s}^{-1}$ & Determined by fitting \\
$k_{\mathrm{d} 1-}$ & $\mathrm{s}^{-1}$ & Determined by fitting \\
$k_{\mathrm{d} 2+}$ & $\mathrm{s}^{-1}$ & Determined by fitting \\
$k_{\mathrm{d} 2-}$ & $\mathrm{s}^{-1}$ & Determined by fitting \\
\hline
\end{tabular}

"Determined by fitting" means these rates were determined by fitting the GluN1/2A $A_{V-D}$ model to macroscopic currents as described in the text relevant to Figures 3 and 4 . Other rate constants were taken directly from Erreger et al. (2005).

${ }^{a}$ This rate was set to the indicated value at $-100 \mathrm{mV}$ (the voltage at which rates were estimated in Erreger et al. (2005), but differed at other voltages by increasing exponentially with voltage (e-fold for $175 \mathrm{mV}$; Clarke and Johnson, 2008).

$\left(V_{\mathrm{m}, \mathrm{e}}-(-100 \mathrm{mV})\right)$, which was then normalized by dividing by fast conductance for $190 \mathrm{mV}\left(I_{\text {fast }}(190 \mathrm{mV})\right) /(290 \mathrm{mV})$. $_{\text {slow }}$ results from the change in NMDAR conductance that occurs after the voltage is stepped to $V_{\mathrm{m}, \mathrm{e}}$, so $\mathrm{g}_{\text {slow }}$ was calculated as $I_{\text {slow }}\left(V_{\mathrm{m}, \mathrm{e}}\right) /\left(V_{\mathrm{m}, \mathrm{e}}-V_{\text {rev }}\right)$, which then was normalized by dividing by fast conductance for $190 \mathrm{mV}$. $V_{\text {rev }}$ is the reversal potential for current flow through GluN1/2A receptors, which we measured as $-7 \mathrm{mV}$.

Model fitting and current simulations were performed using SCoP 4.0 (Simulation Resources). The model of GluN1/2A receptors that we used (Fig. $3 A$ ) has the same structure as the model we used to investigate voltage-dependent gating of GluN1/2B receptors (Clarke and Johnson, 2008) and is based on previously developed GluN1/2B and GluN1/2A models (Banke and Traynelis, 2003; Erreger et al., 2005). State transition rates were fixed to the values for GluN1/2A receptors in Erreger et al. (2005) (Table 1), except for $k_{\mathrm{s}+}$ (the forward rate representing GluN2A subunit conformational change) and rates of entry into and recovery from desensitized states, which were set as described in Results. Because our GluN1/2A receptor model was based on the work of Erreger et al.
(2005), it is important to compare experimental conditions. Most conditions were similar, including expression systems (HEK293 cells in Erreger et al., 2005; HEK293T cells here), temperature (room temperature in both cases), and $\mathrm{pH}$ ( $\mathrm{pH} 7.3$ external solution, $\mathrm{pH} 7.35$ pipette solution in Erreger et al., 2005; pH 7.2 external and pipette solution here). Some conditions differed, but should not have affected the results substantially. Although the $\mathrm{Ca}^{2+}$ concentration was $0.5 \mathrm{~mm}$ in Erreger et al. (2005) but $1 \mathrm{~mm}$ here, we found that $0 \mathrm{Ca}^{2+}+$ EGTA solution did not affect depolarization-induced slow relaxations significantly (Results). Although EDTA was used to chelate $\mathrm{Zn}^{2+}$ in Erreger et al., (2005), but was not used in most experiments here, we found that EDTA did not affect depolarization-induced slow relaxations (Fig. $1 F$ ).

When modeling currents in $1 \mathrm{mM} \mathrm{Mg}^{2+}$, corresponding rates in the unblocked and blocked arms of the model were set as equal. Voltagedependent values of the $\mathrm{Mg}_{\mathrm{o}}^{2+}$ blocking rate and unblocking rate (Clarke and Johnson, 2008) were calculated from previously published equations (Antonov and Johnson, 1999).

Data are expressed as means \pm SEM and statistical analysis was performed using 2-tailed Student's $t$ tests unless otherwise noted.

\section{Results}

Voltage dependence of GluN1/2A receptor currents in $0 \mathrm{Mg}_{\mathrm{o}}^{2+}$ To examine potential voltage-dependent gating of GluN1/2A receptors, currents were elicited from HEK 293T cells expressing GluN1/2A receptors by application of $1 \mathrm{~mm}$ glutamate in the continuous presence of $10 \mu \mathrm{M}$ glycine in $0 \mathrm{Mg}_{\mathrm{o}}^{2+}$. GluN1/2A receptor-mediated currents displayed marked desensitization (Fig. 3D,F) and reached a steady-state level after several seconds of continuous agonist application. Once a steady-state current was reached, depolarizing voltage steps were made. The current response to a voltage step from -100 to $190 \mathrm{mV}$ and back to $-100 \mathrm{mV}$ is shown in Figure $1 A$ and responses to three different depolarizing steps are shown at a faster time base in Figure $1 B$. Depolarizing steps caused a rapid outward jump in current, as expected due to the change in driving force, followed by a slower relaxation that increased in amplitude with larger depolarizations (Fig. $1 B, E$ ). Fitting of current relaxations in response to depolar- 
A

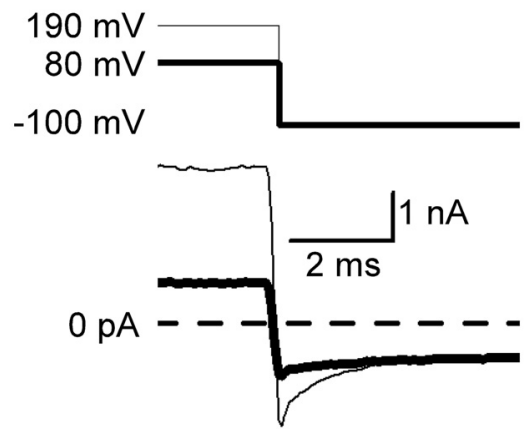

B

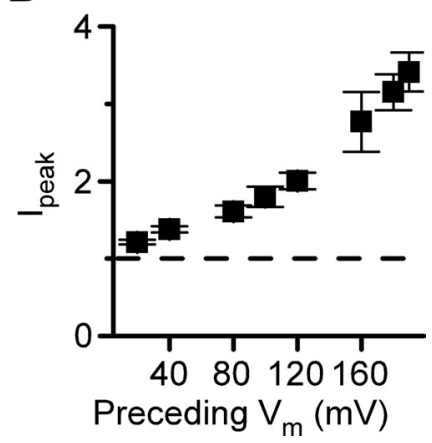

predicted assuming a linear $I-V$ curve with the measured reversal potential of $-7 \mathrm{mV}(0.72)$.

If GluN1/2A receptor $P_{\text {open }}$ exhibits a time-dependent increase during depolarizations, a time-dependent decrease in $P_{\text {open }}$ should be observed when membrane voltage is returned to a hyperpolarized value. Consistent with this prediction, immediately after repolarization to $-100 \mathrm{mV}$, the inward current displayed an initial peak that exceeded the steady-state current level at $-100 \mathrm{mV}$ (Fig. 2A). The repolarization-induced inward current peak $\left(I_{\text {peak }}\right)$ depended significantly (ANOVA, $p<0.001$ ) on the amplitude of the previous depolarization, becoming larger after repolarization from more positive voltages (Fig. $2 B$ ). After the $I_{\text {peak }}$, the current relaxed to the baseline

izing voltage steps required double-exponential equations containing fast $\left(\tau_{\text {fast }},<1 \mathrm{~ms}\right)$ and slow ( $\tau_{\text {slow, }}$ several $\mathrm{ms}$ ) components (Fig. 1C; see Materials and Methods). The value of $\tau_{\text {slow }}$ did not depend significantly on the amplitude of the depolarization (Fig. $1 D$ ). In contrast, $A_{\text {slow }}$ depended significantly (ANOVA, $p<0.001$ ) on the amplitude of the depolarization, becoming larger with increasing depolarization (Fig. $1 E$ ).

$\mathrm{Zn}^{2+}$ is a potent $\left(\mathrm{IC}_{50} \sim 20 \mathrm{nM}\right)$ inhibitor of GluN1/2A receptors. Even the very low $\mathrm{Zn}^{2+}$ concentrations that typically contaminate nominally $\mathrm{Zn}^{2+}$-free solutions may cause significant GluN1/2A receptor inhibition (Paoletti et al., 1997). To determine whether inhibition of NMDAR responses by $\mathrm{Zn}^{2+}$ contaminating our solutions influenced depolarization-induced slow relaxations, we compared $A_{\text {slow }}$ in our normal external solution with an identical solution except for the addition of $10 \mu \mathrm{M}$ EDTA, a very high-affinity $\mathrm{Zn}^{2+}$ chelator $($ Fig. $1 F)$. EDTA had no effect on $A_{\text {slow }}$, suggesting that contaminating $\mathrm{Zn}^{2+}$ did not influence depolarizationinduced slow relaxations.

We also investigated whether elimination of $\mathrm{Ca}^{2+}$, to which NMDARs are highly permeable, influenced depolarizationinduced slow relaxations. We compared $A_{\text {slow }}$ after depolarizations from -65 to $35 \mathrm{mV}$ in normal external solution and in an identical solution except with 0 added $\mathrm{CaCl}_{2}$ and $1 \mathrm{~mm}$ EGTA. $A_{\text {slow }}$ values in normal $\left(1 \mathrm{mM} \mathrm{Ca}^{2+}\right)$ external solution $(9.0 \pm 1.5 \%)$ and in $0 \mathrm{Ca}^{2+} /$ EGTA external solution $(5.1 \pm$ $0.9 \%)$ were not significantly different $(p=0.15)$, which is consistent with previous observations on GluN1/2B receptors (Clarke and Johnson, 2008). It is possible that the apparent trend toward a larger relaxation in $\mathrm{Ca}^{2+}$ reflects a moderate effect of 1 $\mathrm{mM} \mathrm{Ca}^{2+}$ on depolarization-induced relaxations.

The results shown in Figure 1 bear a qualitative resemblance to recordings from GluN1/2B receptors that reflect voltage-dependent gating (Clarke and Johnson, 2008), suggesting that gating of GluN1/2A receptors may also depend on voltage. Voltagedependent gating of GluN1/2B receptors results in a time-dependent increase in open probability $\left(P_{\text {open }}\right)$ after depolarization, which is reflected by a slow component of relaxations after depolarizing voltage jumps (Clarke and Johnson, 2008). If the slow component of GluN1/2A receptor current relaxations results from a depolarization-induced increase in $P_{\text {open }}$, then steady-state current should increase supralinearly at positive voltages. Consistent with this prediction, the ratio of steady-state current at 35 to -65 $\mathrm{mV}(1.05 \pm 0.06)$ was significantly $(p=0.0044)$ higher than current level over several milliseconds and was well fit by a singleexponential equation. These data suggest that the $P_{\text {open }}$ of GluN1/2A receptors is enhanced at depolarized voltages even in the absence of $\mathrm{Mg}_{\mathrm{o}}^{2+}$.

\section{Development and evaluation of GluN1/2A receptor voltage- dependent model in $\mathbf{0} \mathbf{M g}_{\mathrm{o}}^{2+}$}

We next used a computational model to investigate the mechanism by which depolarization enhances GluN1/2A receptor currents. We started by testing the parsimonious hypothesis that the same underlying mechanism is responsible for voltage dependence of GluN1/2A and GluN1/2B receptor currents. To test this hypothesis, we developed a voltage-dependent model of GluN1/2A receptor function (the GluN1/2 $\mathrm{A}_{\mathrm{V}-\mathrm{D}}$ model) using as a template our previously described (Clarke and Johnson, 2008) voltage-dependent GluN1/2B receptor model (the GluN1/2B $\mathrm{V}_{\mathrm{D}-\mathrm{D}}$ model). In the GluN1/2 $A_{V-D}$ model (Fig. $3 A$ ), " $R$ " represents the NMDAR bound only to glycine (all experiments were performed in the continuous presence of $10 \mu \mathrm{M}$ glycine) and " $\mathrm{A}$ " represents a single glutamate molecule. Once the NMDAR binds two glutamate molecules (state $\mathrm{RA}_{2}$ ), the NMDAR can enter one of two desensitized states, $\mathrm{RA}_{2} \mathrm{~d}_{1}$ or $\mathrm{RA}_{2} \mathrm{~d}_{2}$, or proceed toward the open state $\left(\mathrm{RA}_{2}{ }^{*}\right)$. As described previously (Banke and Traynelis, 2003; Erreger et al., 2005), preopening conformational changes associated with the GluN1 (transition to $\mathrm{RA}_{2 \mathrm{f}}$ ) or GluN2 (transition to $\mathrm{RA}_{2 \mathrm{~s}}$ ) subunits connect state $\mathrm{RA}_{2}$ with $\mathrm{RA}_{2}{ }^{*}$. We found (Clarke and Johnson, 2008) that this type of model reproduces GluN1/2B receptor current properties, including those that result from inherent voltage dependence, if $k_{\mathrm{s}+}$ (the forward rate associated with the GluN2 subunit preopening conformational change) exhibits weak exponential (Hille, 2001) dependence on membrane voltage. To determine whether GluN1/2A receptors express the same mechanism and strength of voltage dependence as GluN1/2B receptors, we imposed on $k_{\mathrm{s}+}$ in the GluN1/2A $\mathrm{A}-\mathrm{D}$ model (Fig. $3 A$, red arrows) the same exponential voltage dependence (e-fold per $175 \mathrm{mV}$ ) found to model GluN1/2B receptors accurately (Clarke and Johnson, 2008). However, because of the kinetic differences between GluN1/2A and GluN1/2B receptors, we used rate constants equal to the values (Table 1) determined previously for GluN1/2A receptors (Erreger et al., 2005). Therefore, the value of $k_{\mathrm{s}+}$ at any membrane voltage $\left(V_{\mathrm{m}}\right)$ equaled $k_{\mathrm{s}+}(-100 \mathrm{mV}) * \exp \left[-\left(V_{\mathrm{m}}+100 \mathrm{mV}\right) /(175 \mathrm{mV})\right]$, where $k_{\mathrm{s}+}(-100 \mathrm{mV})$ is the value measured by Erreger et al. (2005) at 
- $100 \mathrm{mV}$. Importantly, GluN1/2A receptors undergo preopening conformational changes more rapidly than GluN1/2B receptors.

We investigated whether the GluN1/ $2 \mathrm{~A}_{\mathrm{V}-\mathrm{D}}$ model reproduces the depolarizationinduced enhancement of GluN1/2A receptor currents, first by examining the voltage dependence of the rapid and slow components of current relaxations in response to voltage jumps. To compare data with model predictions, doubleexponential equations were fit to current relaxations (Fig. 1B) measured during voltage jumps or simulated by the GluN1/ $2 \mathrm{~A}_{\mathrm{V}-\mathrm{D}}$ model. The amplitudes of the fast and slow components were then converted to normalized conductances ( $g_{\text {fast }}$ and $g_{\text {slow; }}$ see Materials and Methods). The values derived from whole-cell recordings demonstrated that $g_{\text {fast }}$ is nearly voltage independent (Fig. 3B, symbols). Model simulations showed that the GluN1/2 $A_{V-D}$ model similarly predicted $g_{\text {fast }}$ to be voltage independent (Fig. $3 B$, red line). Consistent with the data shown in Figure $1 E$, the voltage dependence of GluN1/2A receptor current slow relaxations was reflected by the increase with depolarization of $g_{\text {slow }}$ (Fig. 3C, symbols). Model simulations with the GluN1/2 $\mathrm{A}_{\mathrm{V} \text {-D }}$ model predicted voltage dependence of $g_{\text {slow }}$ similar to measured values up to voltages of $\sim 150 \mathrm{mV}$. As was observed with GluN1/2B receptors (Clarke and Johnson, 2008), the voltage dependence of $g_{\text {slow }}$ appeared to increase sharply at extremely positive voltages, an observation that we did not explore further. The model predictions shown in Figure 3, $B$ and $C$, were made with no adjustable parameters; the values of all parameters were derived from a previous GluN1/2A receptor model (Erreger et al., 2005) and from the voltage dependence of $k_{\mathrm{s}+}$ that we estimated previously for GluN1/2B receptors (Clarke and Johnson, 2008). Desensitization rates in the GluN1/2 $A_{V-D}$ model were set to 0 for Figure $3, B$ and $C$, because desensitization had negligible effects on these rapid depolarization-induced current relaxations. Based on the good agreement between model and data, we further evaluated the ability of the GluN1/2 $\mathrm{A}_{\mathrm{V}-\mathrm{D}}$ model to reproduce voltage-dependent properties of GluN1/2A receptors.

We next compared recorded and simulated current waveforms during voltage steps. Before performing simulations, the desensitization rates and number of receptors, which vary substantially between cells, were determined separately for each cell. Values of these parameters were estimated by fitting the GluN1/ $2 \mathrm{~A}_{\mathrm{V}-\mathrm{D}}$ model to an application of $1 \mathrm{~mm}$ glutamate at $-65 \mathrm{mV}$ that

A

B
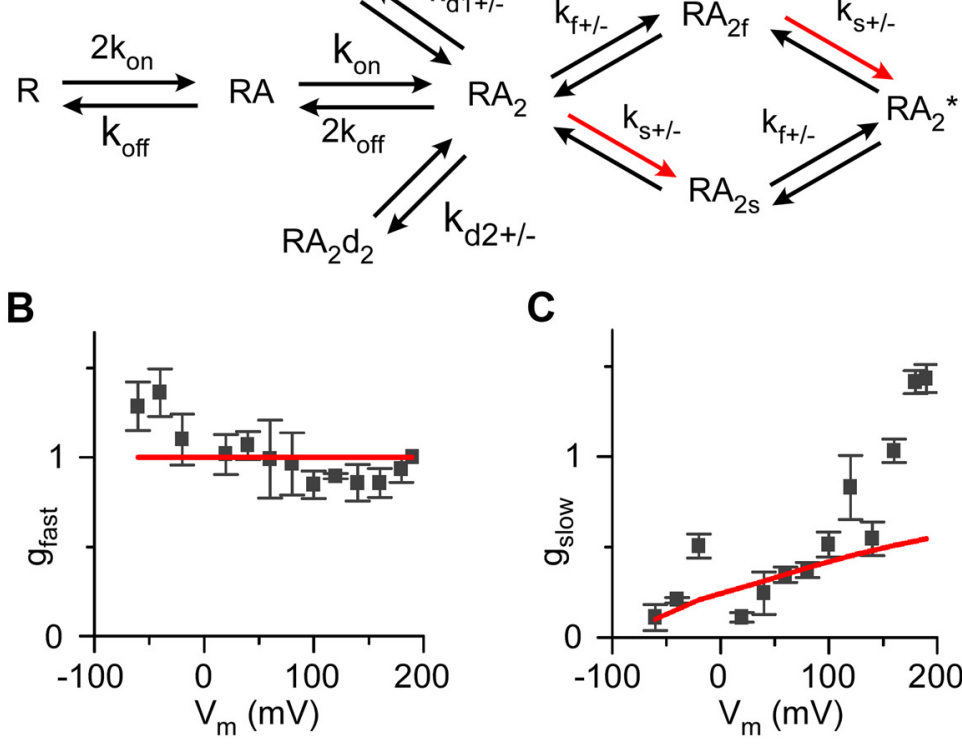

C
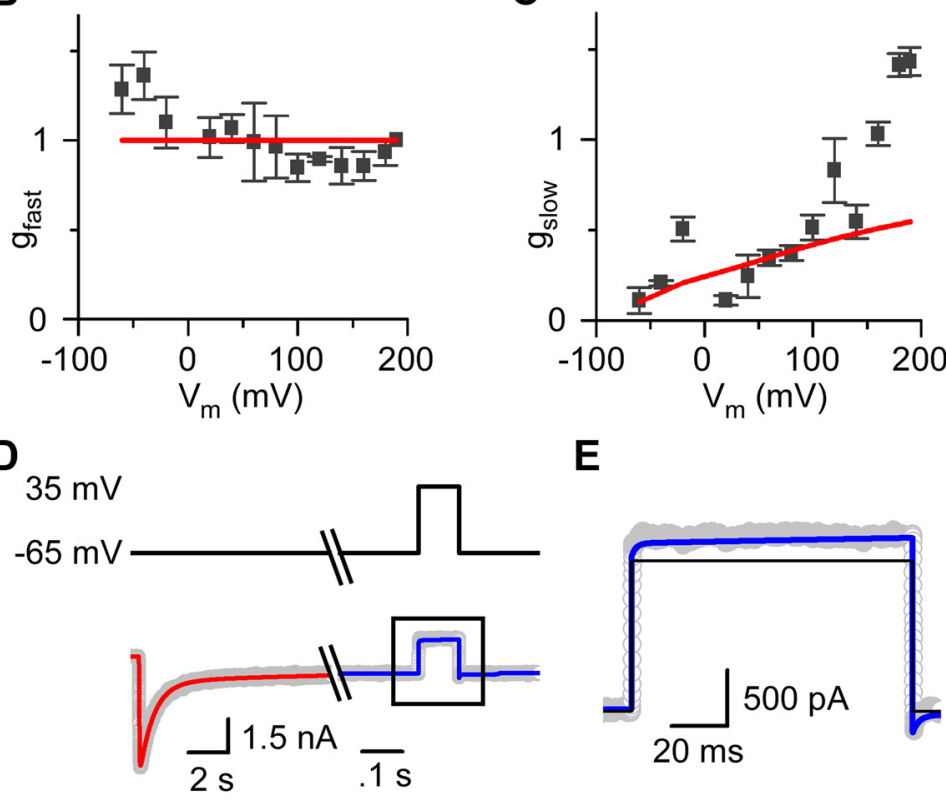

$\mathbf{E}$

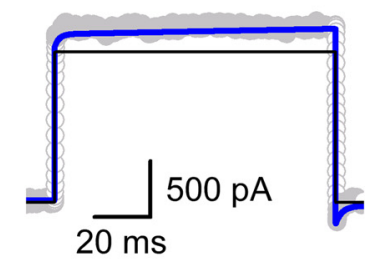

G

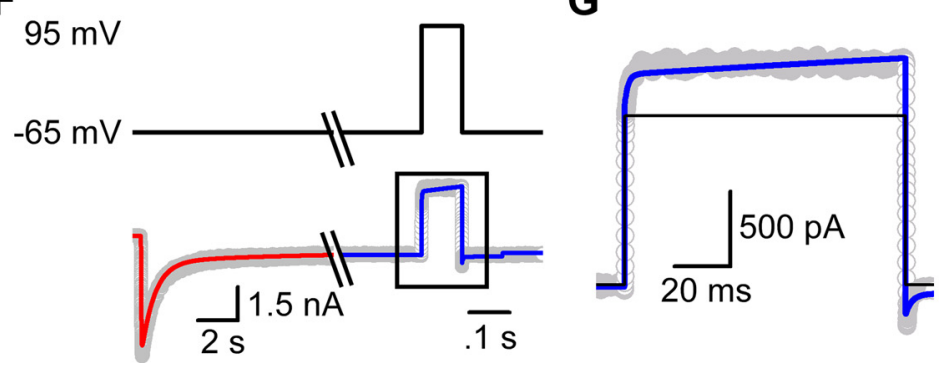

Figure 3. Depolarization-induced slow relaxations in $0 \mathrm{Mg}_{0}^{2+}$ can be reproduced by a GluN1/2A receptor model that incorporates voltage-dependent gating. $A$, Kinetic model used to simulate GluN1/2A receptor activation. Red arrows indicate rate that was altered to undergo an e-fold acceleration per $175 \mathrm{mV}$ depolarization. $\boldsymbol{B}, \boldsymbol{C}$, Amplitudes of each component of double-exponential fits to current relaxations during depolarizing voltage steps (Fig. 1C) were converted to conductances (see Materials and Methods). $g_{\text {fast }}(\boldsymbol{B})$ and $g_{\text {slow }}(\boldsymbol{C})$ derived from fits to whole-cell data are plotted as a function of the voltage during the depolarizing voltage step (symbols). The corresponding values of $g_{\text {fast }}(\boldsymbol{B})$ and $g_{\text {slow }}(\boldsymbol{C})$ derived from GluN1/2A $A_{V-D}$ model simulations also are plotted (red lines). $\boldsymbol{D}$, Current trace (bottom, gray) during application of $1 \mathrm{~mm}$ glutamate in $10 \mu \mathrm{m}$ glycine at $-65 \mathrm{mV}$. Once a steady-state response was reached, the cell was depolarized to $35 \mathrm{mV}$. Results of fitting the GluN1/2 $A_{V-D}$ model to determine desensitization rate constants and number of receptors (red line) and subsequent current simulations with all rates fixed (blue line) are overlaid. Voltage is shown by top trace. $E$, Enlarged view of the current trace (gray) and simulation by the GluN1/2A $A_{V-D}$ model (blue line) in response to a depolarization from -65 to $35 \mathrm{mV}$. Current simulation from a model containing no voltage dependence is overlaid (black line); in this model, $k_{\mathrm{s}+}$ at all voltages equals the value measured by Erreger et al. (2005) at $-100 \mathrm{mV}$. F, G, Same as D and $\boldsymbol{E}$ except the depolarization was from -65 to $95 \mathrm{mV}$.

preceded depolarizations to $35 \mathrm{mV}$ (Fig. 3D) or $95 \mathrm{mV}$ (Fig. 3F). During fitting, only the channel number and desensitization rates were allowed to vary (Table 1 ). Consistent with previous results (Erreger et al., 2005), GluN1/2A receptor current desensitization was biexponential and the fit required two desensitized states. Once excellent fits were obtained (Fig. $3 D, F$, red lines), all rates were fixed and the GluN1/2 $\mathrm{A}_{\mathrm{V}-\mathrm{D}}$ model was used to simulate 


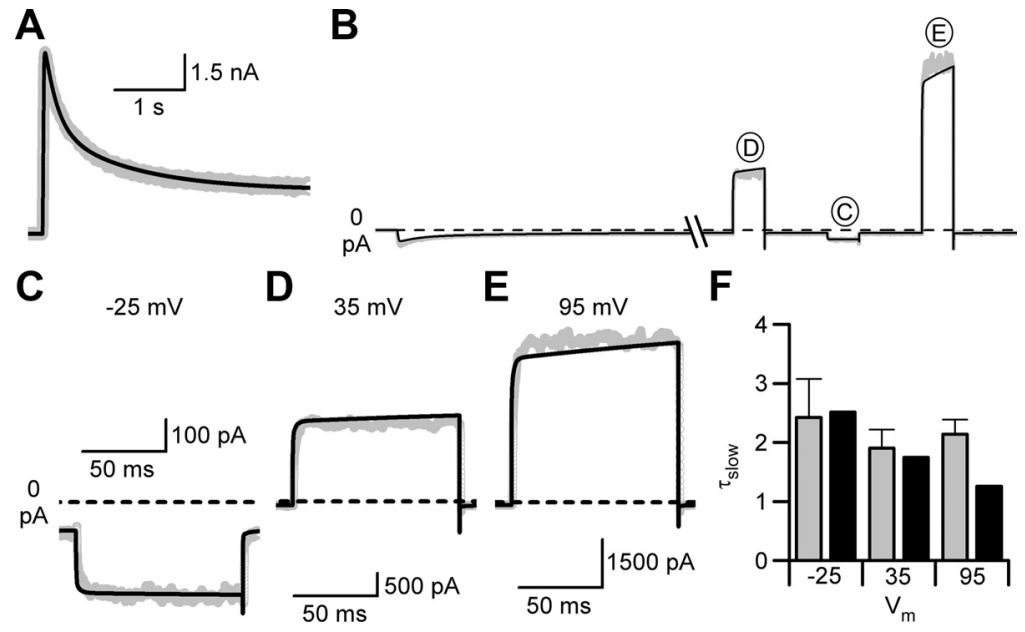

Figure 4. Slow $\mathrm{Mg}_{0}^{2+}$ unblock is reproduced by the GluN1/2A $\mathrm{V}_{\mathrm{V}-\mathrm{D}}$ model. $A$, Current trace (gray line) during application of $1 \mathrm{~mm}$ glutamate in $10 \mu \mathrm{m}$ glycine and $1 \mathrm{~mm} \mathrm{Mg}_{0}^{2+}$ at $35 \mathrm{mV}$. The GluN1/2A $\mathrm{A}_{\mathrm{V}-\mathrm{D}}$ model, expanded to incorporate symmetric block by $\mathrm{Mg}_{0}^{2+}$, was fit to the data with desensitization rates and channel number the only free parameters (black line). $\boldsymbol{B}$, Experimental data (gray line) and current simulations (black line) during application of $1 \mathrm{~mm}$ glutamate in $10 \mu \mathrm{m}$ glycine and $1 \mathrm{~mm} \mathrm{Mg}_{0}^{2+}$ at -65 $\mathrm{mV}$. Once a steady-state response was reached, the cell was depolarized from $-65 \mathrm{mV}$ to $35,-25$, and $95 \mathrm{mV}$. All model parameters were fixed during the simulation. $\boldsymbol{C}-\boldsymbol{E}$, Enlarged views of current traces (gray lines) and GluN1/2A $A_{V-D}$ model simulations (black lines) in response to depolarizations from -65 to $-25 \mathrm{mV}(\boldsymbol{C}), 35 \mathrm{mV}(\boldsymbol{D})$, and $95 \mathrm{mV}(\boldsymbol{E}) . \boldsymbol{F}$, Comparison of $\tau_{\text {slow }}$ values from whole-cell recordings (gray) and from fits to currents simulated by the GluN1/2A $A_{\mathrm{V}-\mathrm{D}}$ model (black) during current relaxations activated by depolarizing steps from $-65 \mathrm{mV}$ to $-25,35$, and $95 \mathrm{mV}$.

currents in response to depolarization to either 35 or $95 \mathrm{mV}$. With no free parameters, the GluN1/2 $\mathrm{A}_{\mathrm{V} \text {-D }}$ model accurately reproduced GluN1/2A receptor-mediated currents in response to depolarizations from -65 to $35 \mathrm{mV}$ (Fig. $3 \mathrm{D}, \mathrm{E}$, blue line) and 95 $\mathrm{mV}$ (Fig. $3 F, G$, blue line). In contrast, a GluN1/2A receptor model identical to the GluN1/2 $\mathrm{A}_{\mathrm{V}-\mathrm{D}}$ model, except with no voltage dependence of $k_{\mathrm{s}+}$, predicted square depolarization-induced current responses and underestimated outward current levels (Fig. 3E,G, black lines). These data suggest that voltagedependent gating of GluN1/2A receptors is sufficient to account for the depolarization-induced potentiation of GluN1/2A receptormediated currents in $0 \mathrm{Mg}^{2+}$.

An apparent disagreement between the GluN1/2 $\mathrm{A}_{\mathrm{V}-\mathrm{D}}$ model and our data involves voltage dependence of $\tau_{\text {slow }}$. Although the model predicts $\tau_{\text {slow }}$ to be weakly voltage dependent, we did not observe significant voltage dependence of $\tau_{\text {slow }}$ (Fig. 1D). We do not believe that this disagreement is meaningful, however, because the large variability in our time constant measurements would not have allowed us to resolve weak voltage dependence of $\tau_{\text {slow }}$.

\section{Evaluation of the GluN1/2 $\mathrm{A}_{\mathrm{V}-\mathrm{D}}$ model in $1 \mathrm{~mm} \mathbf{M g}_{\mathrm{o}}^{2+}$}

Voltage-dependent gating of GluN1/2B receptors results not only in inherent voltage dependence, but also in the slow component of $\mathrm{Mg}_{\mathrm{o}}^{2+}$ unblock from GluN1/2B receptors (Clarke and Johnson, 2008). We next determined whether the slow component of $\mathrm{Mg}_{\mathrm{o}}^{2+}$ unblock from GluN1/2A receptors also results from voltage-dependent gating. The slow component of $\mathrm{Mg}_{\mathrm{o}}^{2+}$ unblock is slower from GluN1/2B than from GluN1/2A receptors (Clarke and Johnson, 2006). Therefore, we initially found it unlikely, although nevertheless worth testing, that slow $\mathrm{Mg}_{\mathrm{o}}^{2+}$ unblock of both receptor subtypes could result from equal voltage dependence of the same single gating parameter $\left(k_{s+}\right)$. We performed comparisons of experimental data and model simulations similar to those shown in Figure $3 D-G$, but in $1 \mathrm{~mm} \mathrm{Mg}^{2+}$. To account for block by $\mathrm{Mg}_{\mathrm{o}}^{2+}$, we used a model identical to that shown in Figure $3 A$, except that a "blocked arm" was added to the GluN1/ $2 \mathrm{~A}_{\mathrm{V}-\mathrm{D}}$ model (Clarke and Johnson, 2008, their Fig. $4 B$ ). The blocked arm followed a trapping block scheme in which, after $\mathrm{Mg}_{\mathrm{o}}^{2+}$ binds, the NMDAR channel can close and glutamate can unbind, trapping the $\mathrm{Mg}_{\mathrm{o}}^{2+}$ ion in the pore. Similar to the GluN1/2B $\mathrm{B}_{\mathrm{V}-\mathrm{D}}$ model (Clarke and Johnson, 2008), we used a symmetric block model: corresponding rates in the blocked and unblocked arms were set as equal, in contrast to asymmetric models that have been developed to explain slow $\mathrm{Mg}_{\mathrm{o}}^{2+}$ unblock (Kampa et al., 2004; Vargas-Caballero and Robinson, 2004). Desensitization rates and channel number were again determined for each cell by fitting the model to whole-cell responses. However, because GluN1/2A receptor currents are strongly inhibited by $1 \mathrm{mM} \mathrm{Mg}^{2+}$ at $-65 \mathrm{mV}$, the model was fit to whole-cell currents elicited by glutamate application while the cell was held at $35 \mathrm{mV}$. Excellent fits were obtained with a model containing two desensitized states in the unblocked and in the blocked arms of the model (Fig. $4 A$, black line).

To compare model simulations and recordings of depolarization-induced slow $\mathrm{Mg}_{\mathrm{o}}^{2+}$ unblock, the membrane potential was returned to $-65 \mathrm{mV}$ after the desensitization rates and number of receptors were estimated and the values were fixed in the model. Glutamate was reapplied in the continued presence of $1 \mathrm{mM} \mathrm{Mg}^{2+}$ and, once a steady-state current level was reached, the voltage was stepped from $-65 \mathrm{mV}$ to $-25,35$, and $95 \mathrm{mV}$ (Fig. 4B). With no free parameters, the GluN1/2A $\mathrm{V}_{\mathrm{D}-\mathrm{D}}$ model accurately simulated (Fig. $4 B-E$, black lines) the current waveforms recorded in $1 \mathrm{mM} \mathrm{Mg}_{\mathrm{o}}^{2+}$.

Agreement between model and data were assessed quantitatively by comparing the time constants of the slow component of depolarization-induced relaxations in whole-cell recordings and simulations. For whole-cell recordings, current relaxations were fit in most cases with a double-exponential equation and the slower exponential component was used to quantify the time constant $\left(\tau_{\text {slow }}\right.$; Fig. $4 F$, gray bars) of the slow component. In a few cases, a triple-exponential equation was used because of a small $(<10 \%)$, slow $(\tau>100 \mathrm{~ms})$ component observed in current relaxations; in these cases, the intermediate time constant was used as $\tau_{\text {slow. }}$. In simulations used for Figure $4 F$, the GluN1/2A $\mathrm{V}_{\mathrm{V}-\mathrm{D}}$ model was used with no adjustable parameters; desensitization rates were fixed at average values determined from fits as shown in Figure $4 A$ to three cells (average values \pm SEM were as follows: $\mathrm{k}_{\mathrm{d} 1+}, 107 \pm 3 \mathrm{~s}^{-1} ; \mathrm{k}_{\mathrm{d} 1-}, 3.50 \pm 0.84 \mathrm{~s}^{-1} ; \mathrm{k}_{\mathrm{d} 2+}, 46.7 \pm 1.23 \mathrm{~s}^{-1}$; $\left.\mathrm{k}_{\mathrm{d} 2-}, 0.41 \pm 0.09 \mathrm{~s}^{-1}\right)$. Simulated currents were fit with multiexponential equations; accurate fits of the noiseless simulations required five-component exponential equations. The fastest three of the five components $\left(\tau_{1}-\tau_{3}\right)$ had values $<1 \mathrm{~ms}$ and thus are likely to correspond to $\tau_{\text {fast }}$ of fits to data. The remaining two components had average values of $\sim 2 \mathrm{~ms}\left(\tau_{4}\right)$ and $\sim 220 \mathrm{~ms}\left(\tau_{5}\right)$. $\tau_{5}$ is likely to result from receptors leaving desensitized states (the only states with such slow kinetics), and so we referred to $\tau_{4}$ as the $\tau_{\text {slow }}$ of simulations and compared its value with $\tau_{\text {slow }}$ measured from the data. Relaxations observed in whole-cell recordings did not have an obvious component corresponding to the slowest component $\left(\tau_{5}\right)$ of GluN1/2 $\mathrm{A}_{\mathrm{V}-\mathrm{D}}$ model relaxations, suggesting 
that modeling of desensitization could be refined (Gibb, 2004; Schorge et al., 2005). Good agreement was observed between the values of $\tau_{\text {slow }}$ at all three voltages (Fig. $4 F)$. The ability of simulations based on the GluN1/2A $A_{V-D}$ model to reproduce slow $\mathrm{Mg}_{\mathrm{o}}^{2+}$ unblock strongly supports the hypothesis that slow $\mathrm{Mg}_{\mathrm{o}}^{2+}$ unblock results from voltage-dependent gating of GluN1/2A receptors. This hypothesis is further supported by the observation that, after depolarizations from -65 to $95 \mathrm{mV}$, the $\tau_{\text {slow }}$ of current relaxations in $0 \mathrm{Mg}^{2+}$ $(2.44 \pm 0.94 \mathrm{~ms})$ and of slow $\mathrm{Mg}_{\mathrm{o}}^{2+} \mathrm{un}-$ block in $1 \mathrm{mM} \mathrm{Mg}_{\mathrm{o}}^{2+}(2.14 \pm 0.25 \mathrm{~ms})$ were not significantly different $(p=0.7)$.

The time constant of the slow component of $\mathrm{Mg}_{\mathrm{o}}^{2+}$ unblock is faster at high than at low NMDA concentrations (Clarke and Johnson, 2006). Whether the kinetics of $\mathrm{Mg}_{\mathrm{o}}^{2+}$ unblock depend on glutamate concentration and, if so, whether the concentration dependence of $\mathrm{Mg}_{\mathrm{o}}^{2+}$ unblock is reproduced by NMDAR models is not known. To further test the ability of the GluN1/2 $\mathrm{A}_{\mathrm{V}-\mathrm{D}}$ model to simulate characteristics of GluN1/2A receptor currents, we compared experimental results and model simulations of $\mathrm{Mg}_{\mathrm{o}}^{2+}$ unblock at low and high glutamate concentrations. The experimental conditions were similar to those used in the experiments shown in Figure 4. For each cell modeled, desensitization rates and number of receptors were determined using a glutamate application in $10 \mu \mathrm{M}$ glycine and $1 \mathrm{mM} \mathrm{Mg}^{2+}$ at 35 $\mathrm{mV}$, after which time glutamate was removed and voltage was returned to -65 $\mathrm{mV}$. Model simulations of subsequently recorded GluN1/2A receptor currents were made with no adjustable parameters. Recorded currents to be simulated were generated by glutamate reapplication, followed by a voltage step from -65 to 35 $\mathrm{mV}$ once a steady-state current level was reached. In these experiments, however, GluN1/2A receptor currents were activated by application of either $1 \mu \mathrm{M}$ or $1 \mathrm{mM}$ glutamate (Fig. 5A). In low agonist concentration ( $1 \mu \mathrm{M}$ glutamate), the GluN1/2 $\mathrm{A}_{\mathrm{V}-\mathrm{D}}$ model predicted that $\mathrm{Mg}_{\mathrm{o}}^{2+}$ unblock would proceed more slowly than in high agonist concentration (1 mM glutamate; Fig. 5B, red lines). Experimental data confirmed this prediction, with depolarization-induced $\mathrm{Mg}_{\mathrm{o}}^{2+}$ unblock from GluN1/2A receptors proceeding more slowly when currents were activated by the low agonist concentration (Fig. $5 B$, black lines, $C$ ). The GluN1/2 $\mathrm{A}_{\mathrm{V}-\mathrm{D}}$ model also predicted that steady-state current at 35 $\mathrm{mV}$, relative to steady-state current at $-65 \mathrm{mV}$, should be larger in low than in high agonist concentrations (Fig. $5 D$, red lines). This prediction implies that GluN1/2A receptor responses should be slightly more voltage dependent at low than at high agonist concentrations. Again, the experimental data agreed well with model predictions (Fig. 5D, black lines, E). The overall agreement between GluN1/2 $\mathrm{A}_{\mathrm{V} \text {-D }}$ model simulations and measurements of $\mathrm{Mg}_{\mathrm{o}}^{2+}$ unblock suggest that the slow component of $\mathrm{Mg}_{\mathrm{o}}^{2+}$ unblock from GluN1/2A receptors is a consequence of voltage-dependent receptor gating.

\section{Comparison of GluN1/2 $\mathrm{A}_{\mathrm{V}-\mathrm{D}}$ and GluN1/2B $\mathrm{B}_{\mathrm{V}-\mathrm{D}}$ model predictions and experimental results}

The slow component of $\mathrm{Mg}_{\mathrm{o}}^{2+}$ unblock from GluN1/2A receptors is faster than the slow component of $\mathrm{Mg}_{\mathrm{o}}^{2+}$ unblock from GluN1/2B receptors (Clarke and Johnson, 2006). In the GluN1/ $2 \mathrm{~A}_{\mathrm{V}-\mathrm{D}}$ model developed here and in the previously developed GluN1/2 $\mathrm{B}_{\mathrm{V}-\mathrm{D}}$ model, inherent voltage-dependent gating resulted from voltage dependence of the same magnitude (e-fold for 175 $\mathrm{mV}$ ) of the same single rate constant $\left(k_{\mathrm{s}+}\right)$. It was important to determine whether, despite the identical voltage dependences of $k_{\mathrm{s}+}$ in the two models, the models reproduce the observed difference in kinetics of the slow component of $\mathrm{Mg}_{\mathrm{o}}^{2+}$ unblock. In Figure $6 A$, the predicted current relaxations of the GluN1/2A $\mathrm{V-D}$ model and GluN1/2 $\mathrm{B}_{\mathrm{V}-\mathrm{D}}$ model to the same depolarizing step $(-65$ to $35 \mathrm{mV})$ are compared. The slow component of $\mathrm{Mg}_{\mathrm{o}}^{2+}$ unblock appeared to be faster for the GluN1/2 $\mathrm{A}_{\mathrm{V}-\mathrm{D}}$ model. The 
A

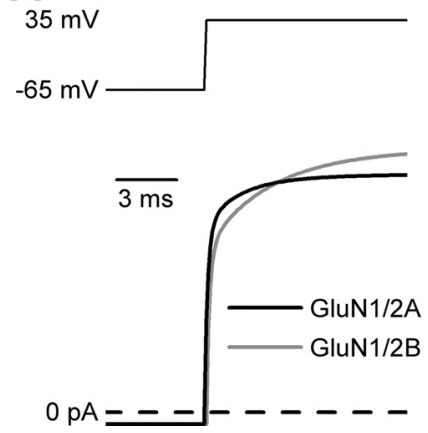

B

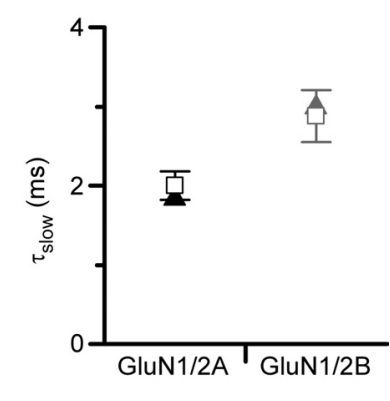

A

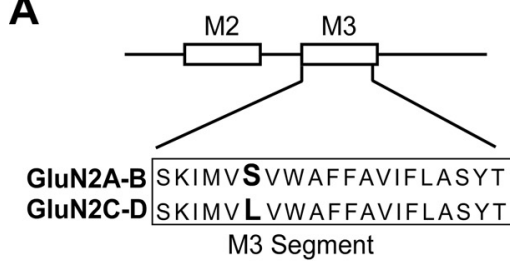

B

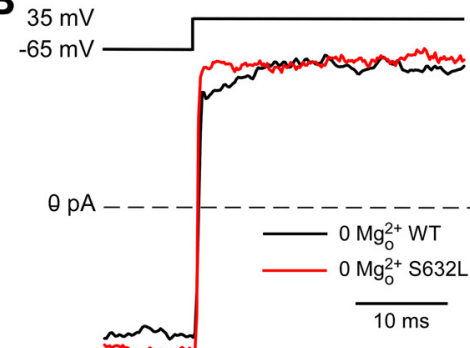

C

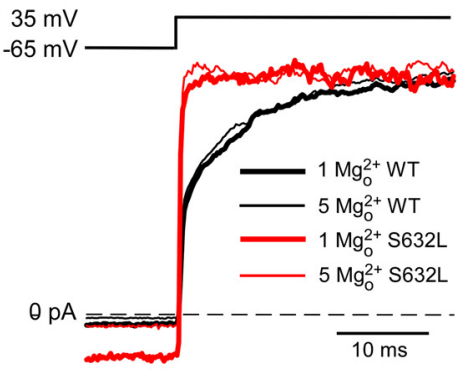

D

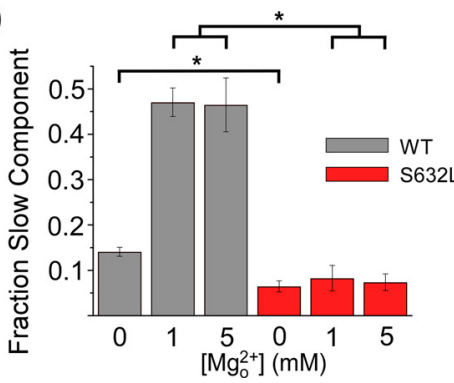

from the GluN1/2 $\mathrm{B}_{\mathrm{V}-\mathrm{D}}$ model; the experimental $\tau_{\text {slow }}$ value was significantly smaller from GluN1/2A receptors than from GluN1/2B receptors; and the $\tau_{\text {slow }}$ value derived from each model was in excellent agreement with the corresponding experimental value (Fig. 6B). These results support the conclusion that GluN1/2A and GluN1/2B receptors exhibit little or no difference in their inherent voltage dependence of gating. Instead, differences in the kinetics of $\mathrm{Mg}_{\mathrm{o}}^{2+}$ unblock from GluN1/2A and GluN1/2B receptors (Clarke and Johnson, 2006) can be explained predominantly by differences between the gating kinetics of these receptor subtypes (Erreger et al., 2005).

\section{The residue at the GluN2 S/L site governs NMDAR voltage- dependent gating}

A single divergent residue in GluN2 subunits is responsible for variation among NMDAR subtypes of multiple channel properties: single-channel conductance, $\mathrm{Ca}^{2+}$ selectivity, and inhibition by $\mathrm{Mg}_{\mathrm{o}}^{2+}$ (Siegler Retchless et al., 2012). The divergent residue, situated near the intracellular end of the $\mathrm{M} 3$ region, is a serine in the GluN2A and GluN2B subunits and a leucine in the GluN2C and GluN2D subunits (Fig. 7A). The site at which the residue is located is termed the GluN2 S/L site (Siegler Retchless et al., 2012). The slow component of $\mathrm{Mg}_{\mathrm{o}}^{2+}$ unblock and depolarization-induced potentiation of NMDARs followed a pattern consistent with a link to the GluN2 S/L site: both proper-

Figure 7. Control by a single divergent GluN2 subunit residue of voltage-dependent gating and slow $\mathrm{Mg}_{0}^{2+}$ unblock. $A$, GluN2 S/L site (residues shown in bold) is located at the intracellular end of the $\mathrm{M} 3$ transmembrane region. Subunit residue numbering begins at the start methionine. The residues at the GluN2 S/L site are as follows: GluN2A(S632), GluN2B(S633), GluN2C(L643), and GluN2D(L657). B, Examples of GluN1/2A (WT; black line) and GluN1/ $2 \mathrm{~A}(\mathrm{S632L}$; red line) current traces recorded from transfected tsA cells during depolarizing step from -65 to $35 \mathrm{mV}$ in $30 \mu \mathrm{m} \mathrm{NMDA}$ and $10 \mu \mathrm{m}$ glycine with $0 \mathrm{Mg}_{0}^{2+}$. C, Same as in $\boldsymbol{B}$ except in the presence of 1 or $5 \mathrm{~mm} \mathrm{Mg}_{0}^{2+}$. Currents in $\boldsymbol{B}$ and $\boldsymbol{C}$ were normalized to steady-state current at $35 \mathrm{mV}$ (average current from $35-40 \mathrm{~ms}$ after the depolarizing step). $\boldsymbol{D}$, Fractional amplitude of the slow component of current relaxations for GluN1/2A (gray) and GluN1/2A(S632L) (red) receptors in 0,1 , and $5 \mathrm{~mm} \mathrm{Mg}_{0}^{2+}$ ( $n=5-7$ in each condition). The amplitude of the slow component measured from double-exponential fits was normalized to the total amplitude of current relaxation in response to depolarizations from -65 to $35 \mathrm{mV}$. Slow components in 0 $\mathrm{Mg}_{0}^{2+}$ were compared using the two-tailed Student's $t$ test; slow components in 1 and $5 \mathrm{~mm}$ $\mathrm{Mg}_{0}^{2+}$ were compared using one-way ANOVA followed by Tukey post hoc comparison. ${ }^{*}$ Significantly different $(p<0.001)$.

ties are expressed in GluN1/2A and GluN1/2B receptors, but not in GluN1/2C or GluN1/2D receptors (Clarke and Johnson, 2006, 2008; and data presented here). We therefore investigated the possibility that the GluN2 S/L site also influences NMDAR subtype dependence of depolarization-induced potentiation and the slow component of $\mathrm{Mgo}^{2+}$ unblock.

We compared the properties of wild-type NMDARs and GluN1/2A(S632L) receptors in which the GluN2 S/L site of the 
A

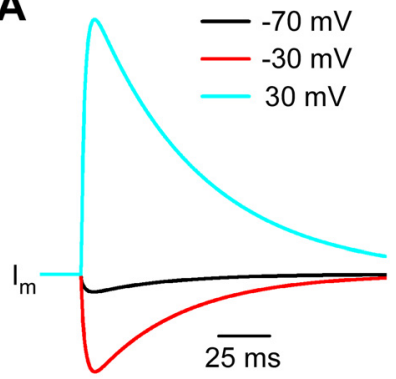

B

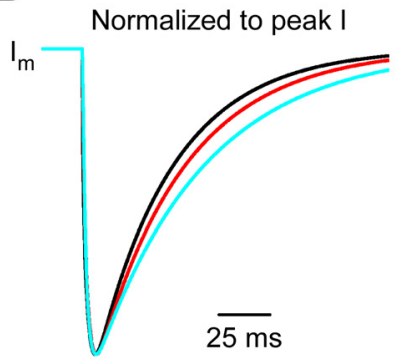

glu

glu

Figure 8. Voltage-dependent decay kinetics of synaptic currents in $1 \mathrm{~mm} \mathrm{Mg}_{0}^{2+}$ simulated by the GluN1/2A $A_{V-D}$ model. $A$, Synaptic currents (top traces) were simulated with the GluN1/2A model in $1 \mathrm{~mm} \mathrm{Mg} 0_{0}^{2+}$ at the indicated membrane voltages by applying a pulse of glutamate (bottom trace) that increased instantaneously from 0 to $1 \mathrm{~mm}$ and then decayed with a singleexponential time constant of $1 \mathrm{~ms}$ (Clements et al., 1992). B B Simulated synaptic currents were normalized to peak current to allow comparison of decay time course. Decay kinetics became slower with depolarization.

GluN2A subunit was mutated from serine (normally in GluN2A and GluN2B subunits) to leucine (found in GluN2C and GluN2D subunits; Fig. 7A). In $0 \mathrm{Mg}_{\mathrm{o}}^{2+}$, the slow component of GluN1/2A(S632L) receptor current relaxations in response to voltage steps from -65 to $35 \mathrm{mV}$ was $48 \%$ as large as the slow component of wild-type GluN1/2A receptors $(p<0.001$; Fig. $7 B, D)$. Addition of $\mathrm{Mg}^{2+}$ did not affect the small remaining slow component of current relaxations recorded from GluN1/ $2 \mathrm{~A}(\mathrm{~S} 632 \mathrm{~L})$ receptors (Fig. $7 C, D)$, suggesting that it may be unrelated to inherent voltage dependence. In $1 \mathrm{~mm} \mathrm{Mg}^{2+}$, the slow component of GluN1/2A(S632L) receptor current relaxations was $15 \%$ as large as the slow component of GluN1/2A receptors $(p<0.001$; Fig. 7C,D). However, because GluN1/2A(S632L) receptors are inhibited by $\mathrm{Mg}_{\mathrm{o}}^{2+}$ with an $\mathrm{IC}_{50}$ similar to that of GluN1/2C and GluN1/2D receptors (Siegler Retchless et al., 2012), $1 \mathrm{~mm} \mathrm{Mg}_{\mathrm{o}}^{2+}$ inhibits GluN1/2A(S632L) receptors approximately fivefold less effectively than wild-type GluN1/2A receptors at $-65 \mathrm{mV}$. It is possible that the reduction of the slow component of $\mathrm{Mg}_{\mathrm{o}}^{2+}$ unblock of GluN1/2A(S632L) receptors in 1 $\mathrm{mM} \mathrm{Mg}_{\mathrm{o}}^{2+}$ results from weaker inhibition by $\mathrm{Mg}_{\mathrm{o}}^{2+}$. We therefore examined current relaxations in $5 \mathrm{mM} \mathrm{Mg}^{2+}$ (Fig. $7 C, D$ ), a concentration that inhibits GluN1/2A(S632L) receptors as effectively as $1 \mathrm{mM} \mathrm{Mg}_{\mathrm{o}}^{2+}$ inhibits GluN1/2A receptors at $-65 \mathrm{mV}$. We found that the slow component of GluN1/2A(S632L) receptor current relaxations in $5 \mathrm{mM} \mathrm{Mg}^{2+}$ was $13 \%$ as large as the slow component of GluN1/2A receptors in $1 \mathrm{mM} \mathrm{Mg}^{2+}(p<0.001$; Fig. $7 C, D)$. Therefore, mutation of the divergent residue at the GluN2 S/L site substantially reduces both depolarizationinduced potentiation and the slow component of $\mathrm{Mg}_{\mathrm{o}}^{2+}$ unblock. The concurrent reduction of both phenomena by a single mutation provides further compelling evidence that depolarizationinduced potentiation and the slow component of $\mathrm{Mg}_{\mathrm{o}}^{2+}$ unblock are a consequence of voltage-dependent gating of NMDARs.

\section{Discussion}

We describe here a millisecond-timescale depolarizationinduced potentiation of GluN1/2A receptor-mediated currents recorded in $0 \mathrm{Mg}_{\mathrm{o}}^{2+}$ (Figs. 1, 2). A model of GluN1/2A receptor activation containing weak voltage dependence of the GluN2A subunit preopening conformational change accurately reproduced multiple properties of GluN1/2A receptor-mediated cur- rents in response to depolarizations in both $0 \mathrm{Mg}_{\mathrm{o}}^{2+}$ (Fig. 3) and 1 $\mathrm{mM} \mathrm{Mgo}_{\mathrm{o}}^{2+}$ (Figs. 4, 5). Models with identical voltage dependence accurately simulated the distinct kinetics of the slow component of $\mathrm{Mg}_{\mathrm{o}}^{2+}$ unblock from GluN1/2A and GluN1/2B receptors (Fig. 6). Remarkably, mutation of the single residue at the GluN2 S/L site in the GluN2A subunit strongly reduced both depolarizationinduced potentiation and slow $\mathrm{Mg}_{\mathrm{o}}^{2+}$ unblock of GluN1/2A receptors (Fig. 7).

\section{Inherent voltage-dependent gating}

Models including inherent voltage-dependent gating have now been shown to accurately simulate currents mediated by both GluN1/2A (data presented here) and GluN1/2B (Clarke and Johnson, 2008) receptors. The form of these models was derived from previously developed kinetic models in which it was hypothesized that GluN1/2A receptors undergo preopening conformational changes more rapidly than GluN1/2B receptors (Banke and Traynelis, 2003; Erreger et al., 2005). Interestingly, incorporation of the same voltage dependence (e-fold per 175 $\mathrm{mV}$ ) into the same gating transition $\left(k_{\mathrm{s}+}\right)$ resulted in the GluN1/ $2 \mathrm{~A}_{\mathrm{V} \text {-D }}$ model accurately reproducing more rapid depolarizationinduced current relaxations than the GluN1/2 $\mathrm{B}_{\mathrm{V}-\mathrm{D}}$ model. Therefore, the differential responses of GluN1/2A and GluN1/2B receptors to depolarization arise predominantly from voltageindependent kinetic differences between the receptor subtypes. The similar underlying voltage dependence of GluN1/2A and GluN1/2B receptors suggests that the receptor structures responsible for voltage dependence do not differ between these NMDAR subtypes.

Numerous previous observations are consistent with the inherent voltage-dependent gating of NMDARs described here. A slow component of depolarization-induced current relaxation in $0 \mathrm{Mg}_{\mathrm{o}}^{2+}$ was observed in recordings from native hippocampal NMDARs (Benveniste and Mayer, 1995; Spruston et al., 1995). In these studies, the slow current relaxation accounted for as much as $23 \%$ of the total response to a depolarization from -100 to 60 $\mathrm{mV}$ and was well fit by an exponential component with a $\tau$ of 2.5 ms (Benveniste and Mayer, 1995). In single-channel recordings from native hippocampal NMDARs, depolarization was observed to increase $P_{\text {open }}$ in $0 \mathrm{Ca}^{2+}$ (Gibb and Colquhoun, 1992), consistent with data presented here. Several studies of NMDAR inhibition by intracellular $\mathrm{Mg}^{2+}$ also included data consistent with inherent voltage-dependent gating. Measurements of $I-V$ curves in $0 \mathrm{Mg}^{2+}$ (both intracellular and extracellular) revealed outward rectification in several preparations: native NMDARmediated currents from cultured cortical neurons (Li-Smerin and Johnson, 1996); GluN1/2A and GluN1/2B receptors expressed in CHO cells (Li-Smerin et al., 2000); and GluN1/2A receptors expressed in Xenopus oocytes (Kupper et al., 1998). Interestingly, outward rectification was greater in whole-cell recordings from neurons than from $\mathrm{CHO}$ cells and was much greater in measurements of mean current from excised neuronal patches than in whole-cell experiments on neurons (Li-Smerin and Johnson, 1996; Li-Smerin et al., 2000). This observation suggests that the inherent voltage dependence of NMDARs may be subject to modulation.

Nowak and Wright (1992) described a voltage-dependent alteration in NMDAR $P_{\text {open }}$ such that the $P_{\text {open }}$ was significantly higher at positive than at negative membrane potentials. Such changes in $P_{\text {open }}$ due to shifts in the frequency of NMDAR channel opening could explain the slow potentiation we report here. However, the change in $P_{\text {open }}$ described by Nowak and Wright (1992) occurred on the time-scale of minutes. 
Therefore, this slower depolarization-induced potentiation may involve mechanisms distinct from the more rapid depolarization-induced current potentiation described here or perhaps may reflect a form of modulation of inherent voltage dependence.

A final voltage-dependent aspect of NMDAR function has been revealed by measurements of the decay kinetics of NMDARmediated EPSCs (NMDAR-EPSCs), which become slower with depolarization (Konnerth et al., 1990; Keller et al., 1991; D'Angelo et al., 1994; Lamotte d'Incamps and Ascher, 2008). The voltage-dependent decay was observed both in the absence and presence of $\mathrm{Mg}_{\mathrm{o}}^{2+}$, but was more pronounced in the presence of $\mathrm{Mg}_{\mathrm{o}}^{2+}$ (Konnerth et al., 1990; Keller et al., 1991). We simulated NMDAR-EPSCs in $1 \mathrm{mM} \mathrm{Mg}_{\mathrm{o}}^{2+}$ over a range of voltages using the GluN1/2 $\mathrm{A}_{\mathrm{V}-\mathrm{D}}$ model and found the model predicts modest slowing of synaptic currents with depolarization (Fig. 8). Additional mechanisms, such as voltage dependence of glutamate transport (Lamotte d'Incamps and Ascher, 2008), may contribute to the robust voltage dependence of NMDAR-EPSC kinetics observed in some preparations. Nevertheless, our results suggest that voltage-dependent gating of NMDARs contributes to the voltage dependence of NMDAR-EPSC decay kinetics.

\section{Slow $\mathrm{Mg}_{\mathrm{o}}^{2+}$ unblock from the channel of NMDARs}

The GluN1/2 $\mathrm{A}_{\mathrm{V}-\mathrm{D}}$ model developed here reproduced accurately not only depolarization-induced current potentiation in $0 \mathrm{mM}$ $\mathrm{Mg}_{\mathrm{o}}^{2+}$, but also the prominent slow component of $\mathrm{Mg}_{\mathrm{o}}^{2+}$ unblock. The GluN1/2 $\mathrm{A}_{\mathrm{V}-\mathrm{D}}$ model is a symmetric block model and thus does not require that the kinetics of NMDAR transitions be affected by $\mathrm{Mg}_{\mathrm{o}}^{2+}$ binding, which is consistent with previous conclusions (Sobolevsky and Yelshansky, 2000; Qian et al., 2002; Blanpied et al., 2005). In previous models developed to account for slow $\mathrm{Mg}_{\mathrm{o}}^{2+}$ unblock, it was proposed that block by $\mathrm{Mg}_{\mathrm{o}}^{2+}$ causes alterations in NMDAR gating, desensitization, and/or agonist unbinding (Kampa et al., 2004; Vargas-Caballero and Robinson, 2004). Although these models are able to predict accurately the slow component of $\mathrm{Mg}_{\mathrm{o}}^{2+}$ unblock, they do not reproduce the depolarization-induced current potentiation in 0 $\mathrm{Mg}_{\mathrm{o}}^{2+}$ described here and previously (Benveniste and Mayer, 1995; Spruston et al., 1995; Clarke and Johnson, 2008). The data presented here strongly support a common molecular mechanism for depolarization-induced current potentiation in $0 \mathrm{Mg}_{\mathrm{o}}^{2+}$ and slow $\mathrm{Mg}_{\mathrm{o}}^{2+}$ unblock: adding voltage dependence to a single kinetic step in the GluN1/2 $\mathrm{A}_{\mathrm{V}-\mathrm{D}}$ model reproduces both phenomena; the kinetics of current potentiation and of slow $\mathrm{Mg}_{\mathrm{o}}^{2+}$ unblock do not differ; and a point mutation at the GluN2 S/L site reduces both phenomena (see below). Although it remains possible that $\mathrm{Mg}_{\mathrm{o}}^{2+}$ block does have limited effects on NMDAR gating, desensitization, and/or agonist binding, we conclude that slow $\mathrm{Mg}_{\mathrm{o}}^{2+}$ unblock results predominantly from voltagedependent gating.

\section{Dependence of voltage-dependent gating and slow $\mathrm{Mg}_{\mathrm{o}}^{2+}$ unblock on the GluN2 S/L site}

The GluN2 S/L site is responsible for NMDAR subtype dependence of multiple channel properties (Siegler Retchless et al., 2012). Here we demonstrated that mutation from serine to leucine of the GluN2 S/L site in GluN2A subunits results in strong reduction of depolarization-induced potentiation in $0 \mathrm{Mg}_{\mathrm{o}}^{2+}$ and of slow $\mathrm{Mg}_{\mathrm{o}}^{2+}$ unblock. Therefore, the GluN2 S/L site governs the NMDAR subtype dependence of voltage-dependent gating and slow $\mathrm{Mg}_{\mathrm{o}}^{2+}$ unblock of NMDARs in addition to inhibition by $\mathrm{Mg}_{\mathrm{o}}^{2+}$, selective permeability to $\mathrm{Ca}^{2+}$, and single-channel con- ductance. Identification of a single-site mutation that diminishes voltage-dependent gating will provide an important tool for further investigation of the mechanistic basis of NMDAR inherent voltage dependence.

Many types of ligand-gated ion channels in addition to NMDARs have been shown to be sensitive to voltage, including nicotinic acetylcholine receptors (Magleby and Stevens, 1972; Ascher et al., 1978), inhibitory glycine receptors (Legendre, 1999), and AMPA receptors (Raman and Trussell, 1995). Sensitivity of receptor gating to voltage has been most commonly proposed to result from either of two mechanisms: movement through the membrane field of charged amino acid residue(s) during gating (Magleby and Stevens, 1972; Auerbach et al., 1996) or voltage-dependent occupation of a permeant ion binding site that influences gating (Ascher et al., 1978). Reduction of voltagedependent gating of NMDARs by the GluN2A(S632L) mutation favors the involvement of voltage-dependent occupation of a permeant ion-binding site in voltage dependence for at least two reasons. First, neither of the residues involved in the mutation, serine or leucine, is charged. This, however, is not a compelling observation because the GluN2 S/L site affects channel properties through interaction with a tryptophan residue on the adjacent GluN1 subunits, GluN1(W608) (Siegler Retchless et al., 2012). The mutation could also reduce allosterically the movement during gating of a charged residue within the membrane. Second, the GluN2A(S632L) mutation strongly affects interactions of ions $\left(\mathrm{Mg}^{2+}, \mathrm{Ca}^{2+}\right.$, and permeant monovalent cations) with the NMDAR channel, but has limited effects on channel gating (Siegler Retchless et al., 2012), suggesting that it is more likely to affect voltage-dependent binding of an ion than movement of a charged residue during gating. Ion binding to NMDARs can influence channel gating (Li-Smerin and Johnson, 1996; Li-Smerin et al., 2001). However, elimination of $\mathrm{Ca}^{2+}$ and the use of symmetric $\mathrm{KCl}$ solutions have minimal effects on GluN1/2B receptor $\tau_{\text {slow }}$ (Clarke and Johnson, 2008) and we report here that elimination of $\mathrm{Ca}^{2+}$ did not affect GluN1/2A receptor $A_{\text {slow }}$ significantly. These data suggest the following hypothesis: the GluN2A(S632L) mutation affects a nonspecific cation-binding site on NMDARs (Li-Smerin and Johnson, 1996; Antonov et al., 1998; Antonov and Johnson, 1999; Li-Smerin et al., 2001; Zhu and Auerbach, 2001) that is occupied in a voltage-dependent manner and the occupation of which can influence channel gating.

\section{References}

Antonov SM, Johnson JW (1999) Permeant ion regulation of N-methyl-Daspartate receptor channel block by $\mathrm{Mg}^{2+}$. Proc Natl Acad Sci U S A 96:14571-14576. CrossRef Medline

Antonov SM, Gmiro VE, Johnson JW (1998) Binding sites for permeant ions in the channel of NMDA receptors and their effects on channel block. Nat Neurosci 1:451-461. CrossRef Medline

Ascher P, Nowak L (1988) The role of divalent cations in the N-methyl-Daspartate responses of mouse central neurones in culture. J Physiol 399: 247-266. Medline

Ascher P, Marty A, Neild TO (1978) Life time and elementary conductance of the channels mediating the excitatory effects of acetylcholine in Aplysia neurones. J Physiol 278:177-206. Medline

Auerbach A, Sigurdson W, Chen J, Akk G (1996) Voltage dependence of mouse acetylcholine receptor gating: different charge movements in di-, mono- and unliganded receptors. J Physiol 494:155-170. Medline

Banke TG, Traynelis SF (2003) Activation of NR1/NR2B NMDA receptors. Nat Neurosci 6:144-152. CrossRef Medline

Benveniste M, Mayer ML (1995) Trapping of glutamate and glycine during open channel block of rat hippocampal neuron NMDA receptors by 9-aminoacridine. J Physiol 483:367-384. Medline

Blanpied TA, Clarke RJ, Johnson JW (2005) Amantadine inhibits NMDA 
receptors by accelerating channel closure during channel block. J Neurosci 25:3312-3322. CrossRef Medline

Clarke RJ, Johnson JW (2006) NMDA receptor NR2 subunit dependence of the slow component of magnesium unblock. J Neurosci 26:5825-5834. CrossRef Medline

Clarke RJ, Johnson JW (2008) Voltage-dependent gating of NR1/2B NMDA receptors. J Physiol 586:5727-5741. CrossRef Medline

Clements JD, Lester RA, Tong G, Jahr CE, Westbrook GL (1992) The time course of glutamate in the synaptic cleft. Science 258:1498-1501. CrossRef Medline

Cull-Candy SG, Leszkiewicz DN (2004) Role of distinct NMDA receptor subtypes at central synapses. Sci STKE 2004:re16. CrossRef Medline

D’Angelo E, Rossi P, Taglietti V (1994) Voltage-dependent kinetics of $\mathrm{N}$-methyl-D-aspartate synaptic currents in rat cerebellar granule cells. Eur J Neurosci 6:640-645. CrossRef Medline

Erreger K, Dravid SM, Banke TG, Wyllie DJ, Traynelis SF (2005) Subunitspecific gating controls rat NR1/NR2A and NR1/NR2B NMDA channel kinetics and synaptic signalling profiles. J Physiol 563:345-358. CrossRef Medline

Gibb AJ (2004) NMDA receptor subunit gating-uncovered. Trends Neurosci 27:7-10. CrossRef Medline

Gibb AJ, Colquhoun D (1992) Activation of N-methyl-D-aspartate receptors by L-glutamate in cells dissociated from adult rat hippocampus. J Physiol 456:143-179. Medline

Gielen M, Siegler Retchless B, Mony L, Johnson JW, Paoletti P (2009) Mechanism of differential control of NMDA receptor activity by NR2 subunits. Nature 459:703-707. CrossRef Medline

Hille B (2001) Ion channels of excitable membranes, Ed 3. Sunderland, MA: Sinauer.

Kampa BM, Clements J, Jonas P, Stuart GJ (2004) Kinetics of $\mathrm{Mg}^{2+}$ unblock of NMDA receptors: implications for spike-timing dependent synaptic plasticity. J Physiol 556:337-345. CrossRef Medline

Keller BU, Konnerth A, Yaari Y (1991) Patch clamp analysis of excitatory synaptic currents in granule cells of rat hippocampus. J Physiol 435:275293. Medline

Konnerth A, Keller BU, Ballanyi K, Yaari Y (1990) Voltage sensitivity of NMDA-receptor mediated postsynaptic currents. Exp Brain Res 81:209212. Medline

Kuner T, Schoepfer R (1996) Multiple structural elements determine subunit specificity of $\mathrm{Mg}^{2+}$ block in NMDA receptor channels. J Neurosci 16:3549-3558. Medline

Kupper J, Ascher P, Neyton J (1998) Internal $\mathrm{Mg}^{2+}$ block of recombinant NMDA channels mutated within the selectivity filter and expressed in Xenopus oocytes. J Physiol 507:1-12. CrossRef Medline

Lamotte d'Incamps B, Ascher P (2008) Four excitatory postsynaptic ionotropic receptors coactivated at the motoneuron-Renshaw cell synapse. J Neurosci 28:14121-14131. CrossRef Medline

Legendre P (1999) Voltage dependence of the glycine receptor-channel kinetics in the zebrafish hindbrain. J Neurophysiol 82:2120-2129. Medline

Levis RA, Rae JL (1992) Constructing a patch clamp setup. Methods Enzymol 207:14-66. CrossRef Medline

Li-Smerin Y, Johnson JW (1996) Effects of intracellular $\mathrm{Mg}^{2+}$ on channel gating and steady-state responses of the NMDA receptor in cultured rat neurons. J Physiol 491:137-150. Medline

Li-Smerin Y, Aizenman E, Johnson JW (2000) Inhibition by intracellular
$\mathrm{Mg}^{2+}$ of recombinant $\mathrm{N}$-methyl-D-aspartate receptors expressed in Chinese hamster ovary cells. J Pharmacol Exp Ther 292:1104-1110. Medline

Li-Smerin Y, Levitan ES, Johnson JW (2001) Free intracellular $\mathrm{Mg}^{2+}$ concentration and inhibition of NMDA responses in cultured rat neurons. J Physiol 533:729-743. CrossRef Medline

Magleby KL, Stevens CF (1972) A quantitative description of end-plate currents. J Physiol 223:173-197. Medline

Monyer H, Sprengel R, Schoepfer R, Herb A, Higuchi M, Lomeli H, Burnashev N, Sakmann B, Seeburg PH (1992) Heteromeric NMDA receptors: molecular and functional distinction of subtypes. Science 256:1217-1221. CrossRef Medline

Nowak L, Bregestovski P, Ascher P, Herbet A, Prochiantz A (1984) Magnesium gates glutamate-activated channels in mouse central neurones. Nature 307:462-465. CrossRef Medline

Nowak LM, Wright JM (1992) Slow voltage-dependent changes in channel open-state probability underlie hysteresis of NMDA responses in $\mathrm{Mg}^{2+}$. free solutions. Neuron 8:181-187. CrossRef Medline

Paoletti P, Ascher P, Neyton J (1997) High-affinity zinc inhibition of NMDA NR1-NR2A receptors. J Neurosci 17:5711-5725. Medline

Qian A, Antonov SM, Johnson JW (2002) Modulation by permeant ions of $\mathrm{Mg}^{2+}$ inhibition of NMDA-activated whole-cell currents in rat cortical neurons. J Physiol 538:65-77. CrossRef Medline

Qian A, Buller AL, Johnson JW (2005) NR2 subunit-dependence of NMDA receptor channel block by external $\mathrm{Mg}^{2+}$. J Physiol 562:319-331. CrossRef Medline

Raman IM, Trussell LO (1995) Concentration-jump analysis of voltagedependent conductances activated by glutamate and kainate in neurons of the avian cochlear nucleus. Biophys J 69:1868-1879. CrossRef Medline

Schorge S, Elenes S, Colquhoun D (2005) Maximum likelihood fitting of single channel NMDA activity with a mechanism composed of independent dimers of subunits. J Physiol 569:395-418. CrossRef Medline

Siegler Retchless B, Gao W, Johnson JW (2012) A single GluN2 subunit residue controls NMDA receptor channel properties via intersubunit interaction. Nat Neurosci 15:406-S2. CrossRef Medline

Sobolevsky AI, Yelshansky MV (2000) The trapping block of NMDA receptor channels in acutely isolated rat hippocampal neurones. J Physiol 526: 493-506. CrossRef Medline

Spruston N, Jonas P, Sakmann B (1995) Dendritic glutamate receptor channels in rat hippocampal CA3 and CA1 pyramidal neurons. J Physiol 482: 325-352. Medline

Stern P, Béhé P, Schoepfer R, Colquhoun D (1992) Single-channel conductances of NMDA receptors expressed from cloned cDNAs: comparison with native receptors. Proc Biol Sci 250:271-277. CrossRef Medline

Traynelis SF, Wollmuth LP, McBain CJ, Menniti FS, Vance KM, Ogden KK, Hansen KB, Yuan H, Myers SJ, Dingledine R (2010) Glutamate receptor ion channels: structure, regulation, and function. Pharmacol Rev 62:405496. CrossRef Medline

Vargas-Caballero M, Robinson HP (2004) Fast and slow voltage-dependent dynamics of magnesium block in the NMDA receptor: the asymmetric trapping block model. J Neurosci 24:6171-6180. CrossRef Medline

Yuan H, Hansen KB, Vance KM, Ogden KK, Traynelis SF (2009) Control of NMDA receptor function by the NR2 subunit amino-terminal domain. J Neurosci 29:12045-12058. CrossRef Medline

Zhu Y, Auerbach A (2001) $\mathrm{K}^{+}$occupancy of the N-methyl-d-aspartate receptor channel probed by $\mathrm{Mg}^{2+}$ block. J Gen Physiol 117:287-298. CrossRef Medline 